\title{
Oxygen Metabolites Stimulate Release of High-Molecular-Weight Glycoconjugates by Cell and Organ Cultures of Rodent Respiratory Epithelium via an Arachidonic Acid-dependent Mechanism
}

\author{
Kenneth B. Adler, Wendy J. Holden-Stauffer, and John E. Repine* \\ Department of Anatomy, Physiological Sciences, and Radiology, College of Veterinary Medicine, North Carolina State University, \\ Raleigh, North Carolina 27606; *Departments of Medicine, Surgery, and Pediatrics, Webb-Waring Lung Institute, \\ University of Colorado Health Sciences Center, Denver, Colorado 80262
}

\begin{abstract}
Several common pulmonary disorders characterized by mucus hypersecretion and airway obstruction may relate to increased levels of inhaled or endogenously generated oxidants $\left(\mathrm{O}_{2}\right.$ metabolites) in the respiratory tract. We found that $\mathrm{O}_{2}$ metabolites stimulated release of high-molecular-weight glycoconjugates (HMG) by respiratory epithelial cells in vitro through a mechanism involving cyclooxygenase metabolism of arachidonic acid. Noncytolytic concentrations of chemically generated $\mathrm{O}_{2}$ metabolites (purine + xanthine oxidase) stimulated HMG release by cell and explant cultures of rodent airway epithelium, an effect which is inhibitable by coaddition of specific $\mathrm{O}_{2}$ metabolite scavengers or inhibitors of arachidonic acid metabolism. Addition of $\mathrm{O}_{2}$ metabolites to epithelial cells provoked production of $\mathbf{P G F}_{2 a}$, an effect also inhibitable by coaddition of $\mathrm{O}_{2}$ metabolite scavengers or inhibitors of arachidonic acid metabolism. Finally, addition of exogenous $\mathbf{P G F}_{2 a}$ to cell cultures stimulated HMG release. We conclude that $\mathrm{O}_{2}$ metabolites increase release of respiratory HMG through a mechanism involving cyclooxygenase metabolism of arachidonic acid with production mainly of PGF $_{2 a}$. This mechanism may be fundamental to the pathogenesis of a variety of lung diseases associated with hypersecretion of mucus and/or other epithelial fluids, as well as a basic cellular response to increased oxidants. (J. Clin. Invest. 1990. 85:75-85.) airway • mucin • oxidants
\end{abstract}

\section{Introduction}

Mucus hypersecretion characterizes a number of common pulmonary disorders associated with exposure to inhaled or endogenously generated oxidants. Inhalation of cigarette smoke (1), particulate (2) and gaseous (3) air pollutants, and hyperoxia (4) cause mucus hypersecretion and have been suspected to increase the oxidant load on respiratory epithelium. In addition, locally increased levels of chemotaxins and mediators of inflammation (5) may provoke release of excess $\mathrm{O}_{2}$

This work was presented in part at the Annual Meeting of the American Thoracic Society/American Lung Association, New Orleans, LA, May 1987, and UCLA Winter Symposium: "Oxy-radicals in Molecular Biology and Pathology," Park City, UT, January 1988.

Received for publication 25 January 1989 and in revised form 22 August 1989.

J. Clin. Invest.

(c) The American Society for Clinical Investigation, Inc.

$0021-9738 / 90 / 01 / 0075 / 11 \$ 2.00$

Volume 85, January 1990, 75-85 metabolites from recruited neutrophils and mononuclear phagocytes. Toxic $\mathrm{O}_{2}$ metabolites can induce a spectrum of lesions in the respiratory tract, as well as pulmonary vasculature and parenchyma, and have been associated with acute lung injury, permeability edema, airways hyperreactivity, small airways disease, endothelial injury, vasoconstriction, adult respiratory distress syndrome, and fibrosis (6-8).

Hypersecretion of respiratory mucus also occurs after inhalation of noxious gaseous (9) and particulate (10) material, as well as in response to endogenous mediators of inflammation (11). A key to modulating an association between oxidant stress and mucus hypersecretion could be activation of arachidonic acid metabolism within airway epithelium. Reactive oxygen species can provoke release of arachidonic acid from membrane phospholipids and activate both the cyclooxygenase and lipoxygenase metabolic pathways (12). Thus, exposure to $\mathrm{O}_{2}$ metabolites could lead to increased synthesis of several bioactive eicosanoids which, in turn, could stimulate secretion of airway mucus (13). Conversely, a "by-product" of both cyclooxygenase and lipoxygenase metabolism of arachidonic acid could be production of toxic oxygen species intracellularly (14). These suggested interactions led us to postulate that $\mathrm{O}_{2}$ metabolites could stimulate release of mucinlike glycoproteins from respiratory epithelium through a mechanism involving metabolism of arachidonic acid.

The purpose of our studies was to determine if and how oxidant exposure stimulates release of mucinlike glycoproteins by airway epithelium. To address these questions, the effects of chemically (enzymatically)-generated $\mathrm{O}_{2}$ metabolites on secretion/release of high-molecular-weight glycoconjugates $(\mathrm{HMG})^{1}$ was examined in organotypic primary cultures of guinea pig tracheal epithelial cells $(15,16)$ and in organ cultures (explants) of guinea pig and rabbit trachea (11).

\section{Methods}

Sources of reagents. Healthy, infection-free guinea pigs (200-250 g $\mathrm{VAF} /+$ Hartley males) or rabbits (2 kg New Zealand White males) were purchased from Charles River Breeding Laboratories, Inc., Wilmington, MA. Waymouth's MB 752/1 medium, gentamycin, nystatin and Hanks' balanced salts solution (HBSS) were obtained from Gibco Laboratories, Grand Island, NY. Dazoxiben was a generous gift from Hoffmann La Roche, Inc., Nutley, NJ. Xanthine oxidase isolated from bovine milk without use of proteases (17) was kindly donated by Dr. Joe M. McCord, University of South Alabama, Mobile, AL. PC-1

1. Abbreviations used in this paper: CAT, catalase; DMTU, dimethylthiourea; GO, glucose oxidase; HETE, hydroxyeicosatetraenoic acid; HMG, high-molecular-weight glycoconjugates; LDH, lactate dehydrogenase; NDGA, nordihydroguiaretic acid; XO, xanthine oxidase. 
medium was bought from Ventrex Corp., Portland, ME. Cell culture chambers were constructed as described previously (16) or purchased from either Millipore Corp., Bedford, MA, or Costar Data Packaging Corp., Cambridge, MA. Matrigel was purchased from Collaborative Research, Inc., Boston MA; vitrogen from Collagen Corp., Palo Alto, CA; $\mathrm{H}_{2} \mathrm{O}_{2}$ from J. T. Baker Chemical Co., Phillipsburg, NJ; Agarose CL-4b from Pharmacia Fine Chemicals, Piscataway, NJ; and Optifluor scintillation fluid from Packard Instrument Co., Inc., Downers Grove, IL. Glucosamine $\mathrm{HCl}\left[\mathrm{D}-6-{ }^{3} \mathrm{H}(\mathrm{N})\right]$, sp act $30 \mathrm{Ci} / \mathrm{mmol}$, and arachidonic acid $\left[5,6,8,9,11,12,14,15-{ }^{3} \mathrm{H}(\mathrm{N})\right]$, sp act $60-100 \mathrm{Ci} / \mathrm{mmol}$, were purchased from New England Nuclear, Boston, MA: All other chemicals, including purine, xanthine, xanthine oxidase (XO), $\beta$-D-glucose, glucose oxidase (GO), indomethacin, nordihydroguiaretic acid (NDGA), superoxide dismutase (SOD), catalase (CAT), polyethylene glycol (PEG) and PEG-conjugated catalase (PEG-CAT), mannitol, dimethylthiourea (DMTU), ovine testicular hyaluronidase (type VI-S), cytochrome $c$, sodium azide, ammonium sulfate, and potassium thiocyanate, were purchased from Sigma Chemical Co., St. Louis, MO.

Organotypic culture of respiratory epithelial cells. Primary airway epithelial cells were cultured utilizing an organotypic culture system developed in this laboratory $(15,16)$. Briefly, tracheal epithelial cells were dissociated enzymatically from excised guinea pig airways, washed, and placed on a collagen gel atop a microporous membrane. Cells were cultured with PC-1 medium (without serum, containing gentamycin $[50 \mu \mathrm{g} / \mathrm{ml}]$ and nystatin $[20 \mathrm{U} / \mathrm{ml}]$; changed every $2 \mathrm{~d}$ ) beneath the cells only, with a humidified atmosphere of $95 \%$ air $/ 5 \%$ $\mathrm{CO}_{2}$ maintained above the cells.

Organ culture of tracheal explants. Organ cultures of guinea pig and rabbit tracheal explants were conducted as described (11). Explants were rocked at $5 \mathrm{cycles} / \mathrm{min}$ at $100 \%$ humidity in $95 \%$ air $/ 5 \% \mathrm{CO}_{2}$ at $37^{\circ} \mathrm{C}$ in $0.5 \mathrm{ml}$ of serumless Waymouth's MB 752/1 medium containing $100 \mu \mathrm{g} / \mathrm{ml}$ gentamycin and $25 \mathrm{U} / \mathrm{ml}$ nystatin.

Collection and measurement of released HMG. 8-d cultures were incubated for $18 \mathrm{~h}$ in glucose-free PC-1 medium containing $15 \mu \mathrm{Ci} / \mathrm{ml}$ tritiated glucosamine- $\mathrm{HCl}$. Subsequently, radiolabeled medium was replaced with fresh unlabeled medium. After incubation for $2 \mathrm{~h}$ (baseline period), apical surfaces of the cultures were rinsed with HBSS, and collected for analysis of secreted HMG. Subsequently, cells were incubated with specific test substances (e.g., purine and XO; see below) or paired controls consisting of medium (plus solubilization vehicle, when used) without test substance for a 1-h (experimental) period, at which time the apical washings were collected.

Baseline and experimental period media + washings were assayed for released glycoconjugates using chromatography on Sepharose CL-4B columns $(16,18,19)$. Briefly, samples were adjusted to $\mathrm{pH} 5.0$ using $0.1 \mathrm{M}$ citric acid and then treated with $100 \mathrm{U} / \mathrm{ml}$ ovine testicular hyaluronidase at $37^{\circ} \mathrm{C}$ for $18 \mathrm{~h}$. Subsequently, the mixture was adjusted to neutral $\mathrm{pH}(7.4)$ with $0.2 \mathrm{M} \mathrm{NaOH}$, placed in a boiling water bath for $5 \mathrm{~min}$, and centrifuged at low speed. Supernatants were collected and applied to $1 \times 50-\mathrm{cm}$ columns of Sepharose CL-4B equilibrated with PBS containing $0.1 \%$ (wt/vol) sodium dodecyl sulfate (SDS). Columns then were eluted with this buffer at a constant flow rate of $1 \mathrm{ml} / \mathrm{min}$ and fractions of $1.5 \mathrm{ml}$ collected and mixed with $6 \mathrm{ml}$ of Optifluor. Disintegrations per minute were counted by liquid scintillation. The sum of radioactivity in the five peak fractions of the excluded void volume was defined as the amount of HMG in the sample (20). Released glycoconjugates for each experiment were measured as the ratio of experimental to baseline values and expressed as percentage of control (control = experimental/baseline for medium alone or medium plus vehicle) as described (21).

In another study reported elsewhere, we analyzed the void volume material eluting from these columns to investigate its composition (22). The results of these studies indicated that hyaluronidase-resistant HMG released by epithelial cell and organ cultures and recovered in the void volume fractions of Sepharose CL-4B or 6B columns were mucinlike glycoproteins. Bearing in mind that this type of analysis was not carried out on every sample recovered in this report, we refer to the
HMG released by cell and organ cultures here as hyaluronidase-resistant HMG, as reported elsewhere (23).

For organ cultures, explants from several animals (of a single species) were pooled together in a $60-\mathrm{mm}$ plastic petri dish and incubated for $18 \mathrm{~h}$ in tritiated glucosamine. After incubation, explants were washed extensively in HBSS to remove unincorporated label, and then placed four at a time, randomly, into new $35-\mathrm{mm}$ plastic petri dishes. Released HMG were measured using methods described above for cell cultures, except that baseline and experimental time periods were 5 and $2 \mathrm{~h}$, respectively.

Assessment of cytotoxicity. After exposure to test agents or controls, organ or cell cultures were selected at random and fixed immediately in their dishes in $2.5 \%$ cacodylate-buffered glutaraldehyde for $24 \mathrm{~h}$ before processing for scanning and transmission electron microscopy as described $(11,21)$.

In addition, the cells were assayed for release of cytoplasmic lactate dehydrogenase (LDH) as a marker of cytotoxicity after exposure of six separate cultures to $\mathrm{O}_{2}$ metabolites (purine $[0.02 \mathrm{M}]+\mathrm{XO}[0.02$ $\mathrm{U} / \mathrm{ml}$ ) or control medium without $\mathrm{O}_{2}$ metabolites. Since oxidants may inhibit LDH (24), total LDH (media and cellular content) was measured, and the percentage release of LDH calculated after a 1-h exposure. Media and cells were separated by centrifugation at $400 \mathrm{~g}$ for $15 \mathrm{~min}$. The cells were lysed by incubation with $0.1 \%$ Triton X-100 detergent in medium for $30 \mathrm{~min}$, and the lysates recentrifuged as described above. The supernatants from the cell lysates, and the original medium containing released LDH, were assayed separately for LDH content. The LDH released into the medium was expressed as percentage of cellular LDH content (24). LDH was measured spectrophotometrically at $525 \mathrm{~nm}$ using a commercially purchased kit (Sigma kit no 500).

Generation of $\mathrm{O}_{2}$ metabolites. Superoxide anion $\left(\mathrm{O}_{\overline{2}}\right)$ was generated extracellularly by addition of $\mathrm{XO}$ to purine over a range of concentrations (7). Hydrogen peroxide $\left(\mathrm{H}_{2} \mathrm{O}_{2}\right)$ was generated by addition of $\mathrm{GO}$ to $\beta$-D-glucose $(1 \%)(7,8) . \mathrm{H}_{2} \mathrm{O}_{2}$ at 0.1 and $1.0 \mathrm{mM}$ also was added directly to the cultures. Cell or organ cultures were exposed for 1 or $2 \mathrm{~h}$, respectively.

Treatment with $\mathrm{O}_{2}$ metabolite scavengers or inhibitors of arachidonic acid metabolism. SOD, CAT, mannitol, DMTU, or PEG-CAT were added immediately before addition of purine and XO. Indomethacin or NDGA were added $5 \mathrm{~min}$ before addition of purine + XO. Dazoxiben was added $5 \mathrm{~min}$ before addition of purine $+\mathrm{XO}$ (cell cultures only).

Assessment of $\mathrm{O}_{2}$ metabolite scavenging activity of inhibitors of arachidonic acid metabolism. Xanthine and XO-mediated reduction of cytochrome $c$, as described previously (25), was used to evaluate the ability of indomethacin and NDGA to scavenge $O_{\overline{2}}^{\overline{2}}$ in vitro. The ability of these compounds to scavenge $\mathrm{H}_{2} \mathrm{O}_{2}$ also was assessed by measuring $\mathrm{H}_{2} \mathrm{O}_{2}$ spectrophotometrically at $480 \mathrm{~nm}$ as the ferrithiocyanate complex formed in the presence of $\mathrm{H}_{2} \mathrm{O}_{2}$, as described by Thurman et al. (26).

Assay of arachidonic acid metabolites by high performance liquid chromatography $(H P L C)$. Cell cultures were incubated for $2 \mathrm{~h}$ at $37^{\circ} \mathrm{C}$ with $5 \mu \mathrm{Ci} / \mathrm{ml}$ tritiated arachidonic acid together with $10^{-9} \mathrm{M}$ unlabeled arachidonic acid (27). After incubation, cultures were washed extensively with HBSS and placed into fresh, unlabeled control medium or unlabeled medium containing purine $(0.2 \mathrm{mM})+\mathrm{XO}(0.02$ $\mathrm{U} / \mathrm{ml}$ ). Cultures then were incubated for $2 \mathrm{~h}$ at $37^{\circ} \mathrm{C}$, at which time media from eight separate cultures were pooled. After centrifugation at $2000 \mathrm{rpm}$ for $10 \mathrm{~min}$ at $4^{\circ} \mathrm{C}$, supernatants were placed in 50 -ml tubes to which $16 \mathrm{ml}$ of $100 \%$ ethanol $\left(-20^{\circ} \mathrm{C}\right)$ was added before recentrifugation at $2,500 \mathrm{rpm}$ for $20 \mathrm{~min}$ at $4^{\circ} \mathrm{C}$. Supernatants then were evaporated to dryness, and resuspended in $30 \%$ methanol at $-20^{\circ} \mathrm{C}$ for reverse-phase HPLC using Waters-Millipore instruments (Waters Millipore Corp., Bedford, MA) and an Ultrasphere ODS- $5 \mu$ column (Beckman Instruments, Inc., Palo Alto, CA) $(4.6 \times 250 \mathrm{~mm})$. Two pumps (Waters model 510 ) were connected to a U6K injector previously fitted with a $2-\mathrm{ml}$ loading loop. Pumps were driven by an 
automated gradient controller (Waters model 680). A Waters-Millipore precolumn (RCSS-C18) was used to protect the Beckman column. Absorbance of the eluant was detected with a variable wavelength detector (Waters model 481 LC spectrophotometer).

Absorbance was monitored at $280 \mathrm{~nm}$ for the first 55 min of each run, at which time the wavelength monitor was switched to $229 \mathrm{~nm}$ for the last $35 \mathrm{~min}$. Chromatographs were recorded on a Waters Data Module 740. The solvent system was contained in two reservoirs, each supplying a single pump. One reservoir was filled with $100 \%$ methanol, the other with $10 \%$ methanol and $0.8 \%$ acetic acid, maintained at $\mathrm{pH}$ 6.2. The concentration of methanol in the mobile phase was $50.5 \%$ for the initial $24 \mathrm{~min}$ of each run, $59.5 \%$ for $24-55 \mathrm{~min}, 73 \%$ for $55-75$ minutes, and $100 \%$ for the final $15 \mathrm{~min}$. The flow rate was adjusted to 1 $\mathrm{ml} / \mathrm{min}$, and the eluant was collected in 1-ml fractions. At the end of the procedure, $100 \mu \mathrm{l}$ of each fraction was mixed with $5 \mathrm{ml}$ of scintillation fluid (Optifluor) and the radioactivity counted as disintegrations per minute in a counter (Pharmacia/LKB Corp., Piscataway, NJ). The remainder of the collected fractions was used for RIA (see below). Radioactive standards for each metabolite were tested regularly to check the separation efficiency of the column and retention times of the different metabolites. A total of four replicate experiments were conducted.

Measurement of arachidonic acid metabolites by RIA. RIA was performed on HPLC fractions using kits purchased from Amersham Corp. (Arlington Heights, IL). To avoid interference with RIA by HPLC solvents present in the collected fractions, samples were evaporated under $\mathrm{N}_{2}$ and resuspended in $100 \mu$ lof the respective assay buffers. For peptidyl leukotrienes (LTs) RIA sensitivity was 5 pg per tube, and RIA cross-reactivity was $100 \%$ for $\mathrm{LTC}_{4}, 64 \%$ for $\mathrm{LTD}_{4}$ or $\mathrm{LTE}_{4}$, and $<0.001 \%$ with $\mathrm{LTB}_{4}$. For $\mathrm{LTB}_{4}$, RIA sensitivity was $1.5 \mathrm{pg}$ per tube, and RIA cross-reactivity was $<0.05 \%$ with peptidyl LTs, hydroxyeicosatetraenoic acids (HETEs), or cyclooxygenase products. For $\mathrm{PGF}_{2 \mathrm{a}}$, RIA cross-reactivity was $1.5 \%$ with $\mathrm{PGF}_{1 \mathrm{a}}, 0.01 \%$ with $\mathrm{PGE}_{2}, 0.07 \%$ with $\mathrm{PGE}_{1}, 2.74 \%$ with $\mathrm{PGD}_{2}, 0.7 \%$ with thromboxane $B_{2}$, and $<0.01 \%$ with arachidonic acid. Each RIA was conducted on duplicate samples from four replicate experiments.

Evaluation of statistical significance. Results were evaluated using either Student's $t$ test or the Scheffe procedure for multiple analysis of variance with differing sample size $(28,29)$. A $P$ value of $<0.05$ was considered significant.

\section{Results}

Effects of $\mathrm{O}_{2}$ metabolites on release of $H M G$. Addition of increasing concentrations of $\mathrm{XO}$ to purine progressively increased release of HMG by cultured respiratory epithelial cells (Fig. 1) and tracheal explants (Fig. 2). $\beta$-D-glucose + GO, while generating $\mathrm{H}_{2} \mathrm{O}_{2}$, did not stimulate $\mathrm{HMG}$ release by cell cultures or tracheal explants. Direct addition of $\mathrm{H}_{2} \mathrm{O}_{2}$ at 0.1 and $1.0 \mathrm{mM}$ to the cell cultures also did not affect $\mathrm{HMG}$ release. Addition of purine $+\mathrm{XO}$ isolated without use of proteases stimulated HMG release by cell cultures (data not shown), but purine + heated $\left(90^{\circ} \mathrm{C}\right.$ for $\left.30 \mathrm{~min}\right) \mathrm{XO}$ did not stimulate release of HMG in either system. Scanning and transmission electron microscopic examination of cell and organ cultures did not reveal morphological signs of toxicity: cell sloughing, membrane alterations (such as blebbing), mitochondrial swelling, and vacuolization were not observed in purine

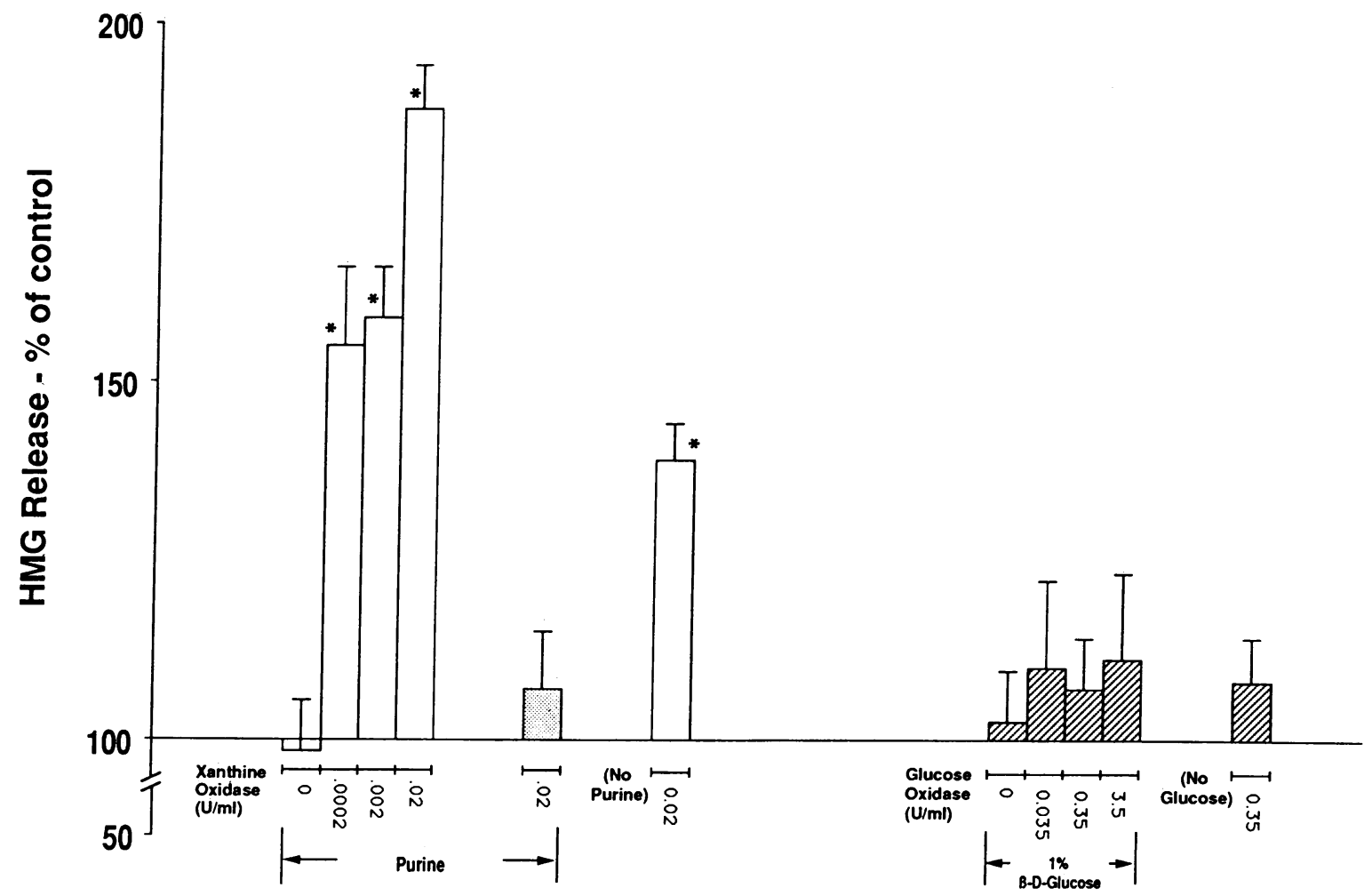

Figure 1. Effect of exposure to oxygen metabolites on HMG release by guinea pig tracheal epithelial cells in culture. Addition of increasing concentrations of xanthine oxidase with $0.2 \mathrm{mM}$ purine elicited a concentration-dependent increase in HMG release. Addition of xanthine oxidase also enhanced secretion significantly even without addition of purine. Heating xanthine oxidase to $90^{\circ} \mathrm{C}$ for 30 min (ø) abolished the stimulatory response. Glucose + glucose oxidase did not increase HMG release. All values are means \pm 1 SEM, expressed as percentage of control for 8-16 determinations. Each asterisk indicates values that are significantly different $(P<0.05)$ from control values based on the Scheffe procedure for multiple analysis of variance $(28,29)$. 


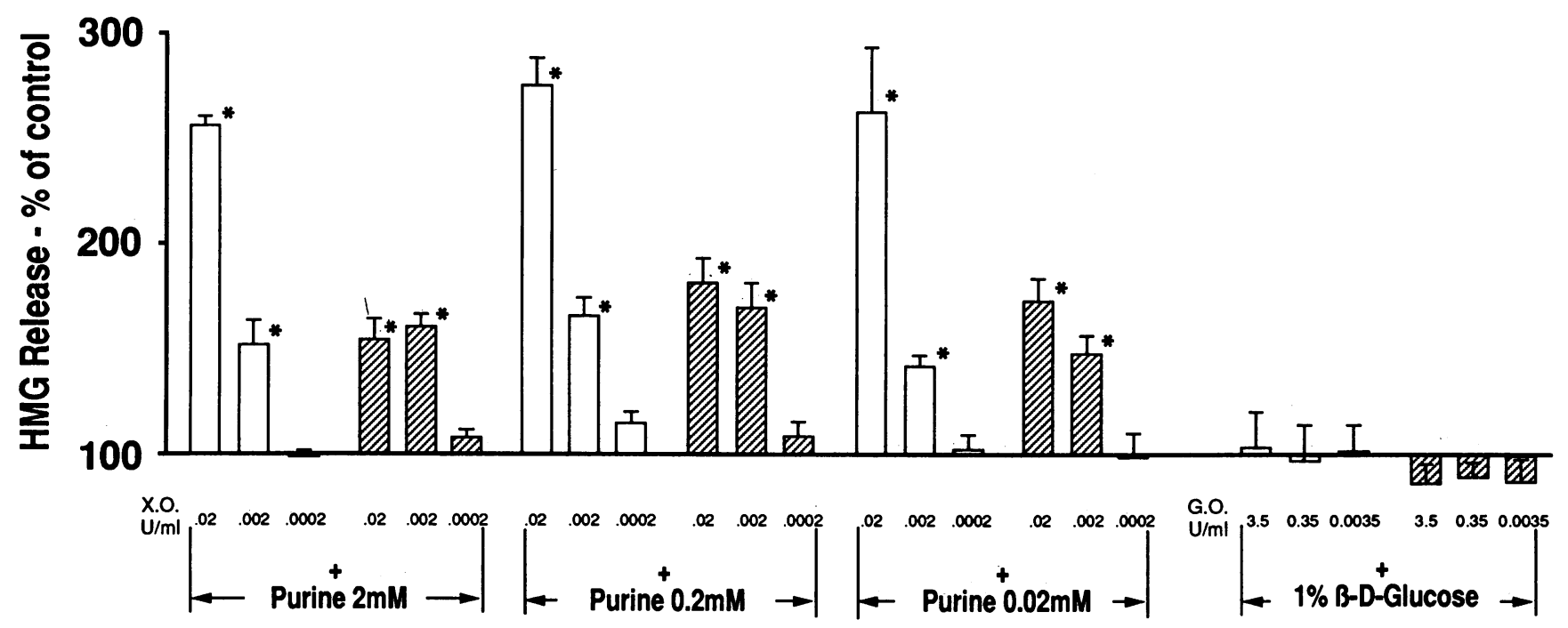

Figure 2. Effect of exposure to oxygen metabolites on HMG release by guinea pig ( $\square$ ) or rabbit ( $($ ) tracheal explants maintained in organ culture. Purine + XO elicited a concentration-dependent increase in HMG release after a 2-h exposure. In contrast, glucose + GO did not increase HMG release. All values are means \pm 1 SEM for 8-16 replicate experiments. Each asterisk indicates a significantly different $(P<0.05)$ value from control value based on the Scheffe procedure for multiple analysis of variance $(28,29)$.

+ XO-treated samples (Fig. 3). In addition, release of LDH by purine + XO-exposed cells was similar to control cells: control cultures released $5.37 \pm 1.1 \%$ of total (cell + medium) $\mathrm{LDH}$ compared with $7.44 \pm 2.3 \%$ of total for $\mathrm{O}_{2}$ metabolite-exposed cells (Total LDH in control and $\mathrm{O}_{2}$ metabolite-exposed cells per milligram of protein were nearly identical.) Thus, $\mathrm{O}_{2}$ metabolites appeared to stimulate release of HMG without causing overt cellular damage or lysis.

Effects of scavengers on $\mathrm{O}_{2}$ metabolite-stimulated $\mathrm{HMG}$ release. Addition of SOD, PEG-CAT, or DMTU inhibited the stimulatory effects of purine + XO on HMG release in both cell (Fig. 4) and organ cultures (Fig. 5). In contrast, addition of CAT, mannitol, or PEG without CAT did not alter the stimulatory effect of purine + XO on HMG release by cell or organ cultures. Neither PEG alone, CAT alone, nor PEG-CAT significantly affected constitutive (nonstimulated control) levels of $\mathrm{HMG}$ release.

Effects of arachidonic acid metabolism inhibitors on $\mathrm{O}_{2}$ metabolite-stimulated HMG release. Addition of either indomethacin or NDGA inhibited HMG release from cells (Fig. 6) or explants (Fig. 7) treated with purine + XO. However, addition of dazoxiben, a thromboxane synthetase inhibitor, did not alter purine + XO-stimulated HMG release by cell cultures (Fig. 6). Indomethacin and NDGA (except at $10^{-5} \mathrm{M}$ ) did not scavenge superoxide anion or $\mathrm{H}_{2} \mathrm{O}_{2}$ in vitro (data not shown) suggesting that $\mathrm{O}_{2}$ metabolites provoked release of $\mathrm{HMG}$ via stimulation of arachidonic acid metabolism.

Assay of cell culture medium for arachidonate metabolites. As illustrated in Fig. 8, HPLC fractionation of culture medium revealed certain prominent peaks in supernatants from $\mathrm{O}_{2}$ metabolite-exposed cells compared to untreated control cells. Medium from control cells showed major peaks which corresponded in retention times to $\mathrm{PGE}_{2}, \mathrm{PGD}_{2}, \mathrm{PGF}_{2 \mathrm{a}}, \mathrm{LTC}_{4}$, and 5-, 12-, and 15-HETE standards. After exposure to purine $+\mathrm{XO}$ for $1 \mathrm{~h}$, enhanced peaks were observed at retention times corresponding to $\mathrm{PGF}_{2 \mathrm{a}}, 5$-HETE, and 15-HETE. Furthermore, sensitive RIA quantification of HPLC peaks for the appropriate metabolites corresponding to retention times of standards revealed that only PGF $_{2 \mathrm{a}}, 15-\mathrm{HETE}$, and 5-HETE were increased significantly in the medium of cell cultures exposed to purine $+\mathrm{XO}$ (Table I).

Effects of arachidonate metabolites on HMG release. Based on results of HPLC and RIA experiments, a range of concentrations of $\mathrm{PGF}_{2 \mathrm{a}}$ and 5- and 15-HETE were added to cell cultures to determine their effects on HMG release. As illustrated in Fig. 9, only $\mathrm{PGF}_{2 \mathrm{a}}$ increased $\mathrm{HMG}$ release significantly.

Effects of $\mathrm{O}_{2}$ metabolite scavengers or arachidonic acid metabolism inhibitors on $P G F_{2 a}$ production. As illustrated in Table II, addition of purine $+\mathrm{XO}$ increased production of $\mathrm{PGF}_{2 \mathrm{a}}$ by cell cultures. Purine $+\mathrm{XO}$-induced increases in PGF $_{2 \mathrm{a}}$ were inhibited by coaddition of PEG-CAT, DMTU, NDGA, or indomethacin. In contrast, addition of mannitol or CAT not bound to PEG did not inhibit $\mathrm{O}_{2}$ metabolite-stimulated increases in production of $\mathrm{PGF}_{2 \mathrm{a}}$, a finding which corresponded to the lack of effect of these agents on $\mathrm{O}_{2}$ metabolitestimulated HMG release (Fig. 4).

\section{Discussion}

We found that $\mathrm{O}_{2}$ metabolites generated extracellularly by purine $+\mathrm{XO}$ provoked a concentration-dependent stimulation of HMG release by cell cultures and explants of rodent respiratory epithelium. Since $\mathrm{O}_{2}$ metabolites stimulated release of HMG by epithelial cells in monolayer culture as well as in explants, secondary interactions of $\mathrm{O}_{2}$ metabolites with other cell types (such as connective tissue cells, mast cells, leukocytes, or platelets) are effectively precluded, and a direct action of $\mathrm{O}_{2}$ metabolites upon epithelial cells is indicated. Moreover, it also is unlikely that proteases contaminating the $\mathrm{XO}$ are responsible for provoking mucin secretion, since $\mathrm{XO}$ isolated from bovine milk without use of proteases (as opposed to the purification procedures used with most commercial preparations) gave similar results. 

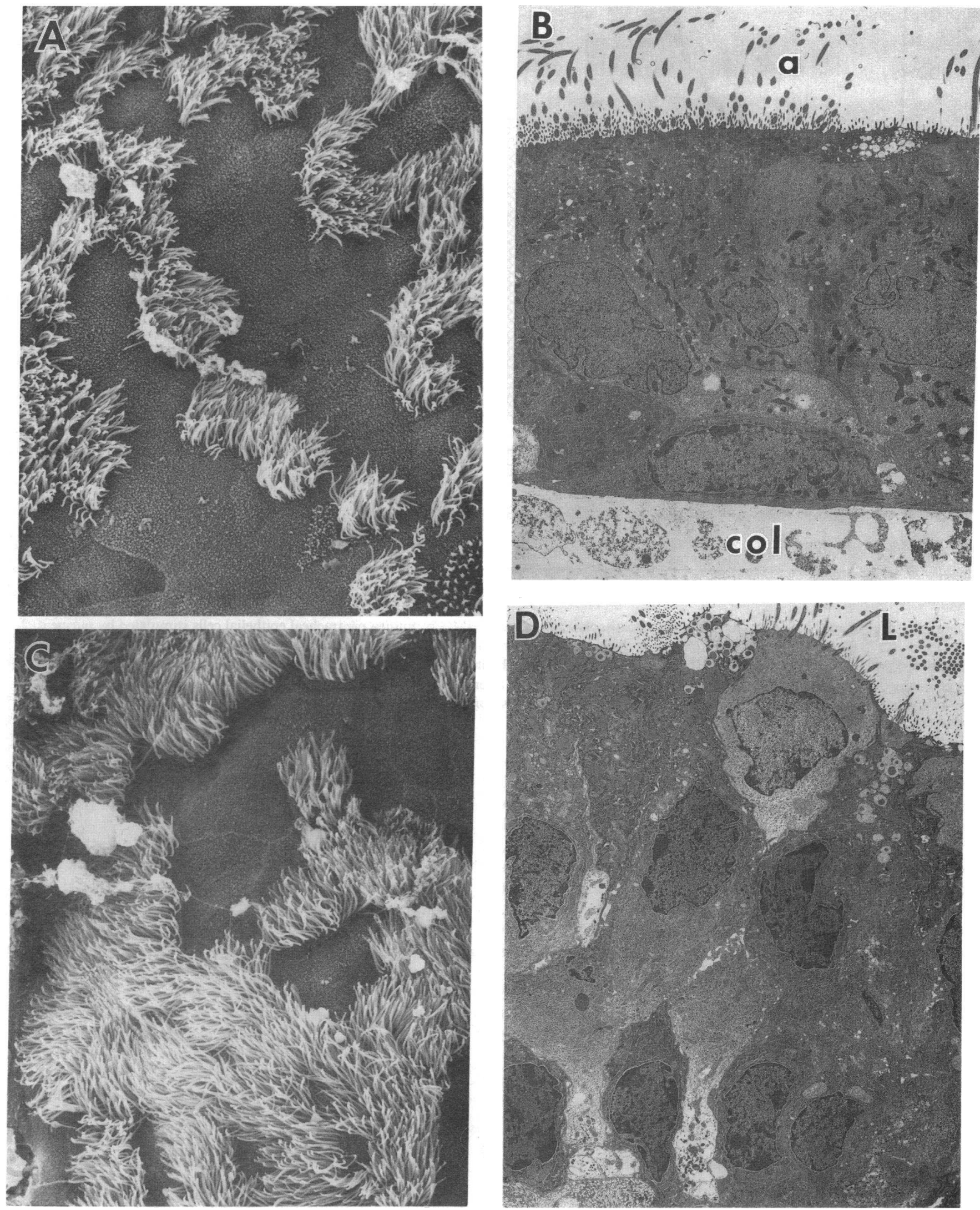

Figure 3. Ultrastructural appearance of epithelium from cultured cells and explants after exposure to a stimulatory concentration of purine $(0.2$ $\mathrm{mM})+\mathrm{XO}(0.02 \mathrm{U} / \mathrm{ml})$ for $2 \mathrm{~h}:(A)$ scanning and $(B)$ transmission microscopic appearance of cells within an 8-d-old culture of guinea pig tracheal epithelium $(C)$ Scanning and $(D)$ transmission microscopic appearance of cells within an explant of guinea pig trachea. Surface epithelial cells appear intact and viable, with no signs of cell sloughing, membrane alterations, cytoplasmic or mitochondrial swelling, or disrupted cellcell junctions or interfaces. $(A) \times 1,700 ;(B) \times 4,350 ;(C) \times 1,900 ;(D) \times 3,325$. $a$, air interface; col, collagen substrate; $L$, luminal aspect. 


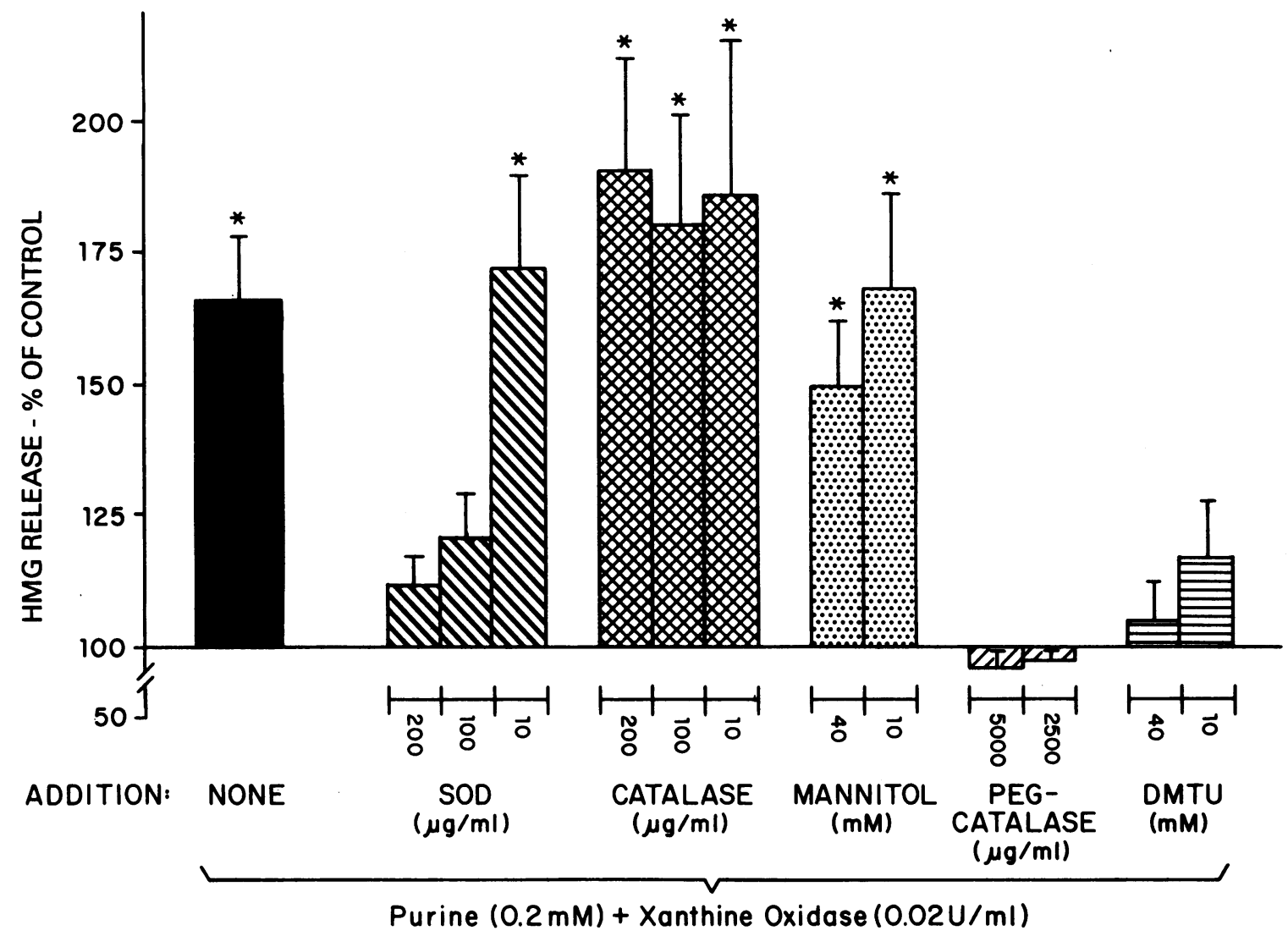

Figure 4. Effect of addition of oxygen metabolite scavengers on release of HMG by guinea pig tracheal epithelial cells stimulated by purine ( 0.2 $\mathrm{mM})$ and $\mathrm{XO}(0.02 \mathrm{U} / \mathrm{ml})$. SOD was inhibitory at the higher concentrations, whereas CAT and mannitol had no effect on stimulated release. However, DMTU, and CAT coupled to PEG, both inhibited $\mathrm{O}_{2}$ metabolite-stimulated HMG release. All values are means \pm 1 SEM, expressed as percentage of control, for 8-12 determinations at each point. Each asterisk indicates values that are significantly different $(P<0.05)$ from control values as assessed by the Scheffe procedure for multiple analysis of variance $(28,29)$.

Enhanced release of HMG did not appear related to a nonspecific toxic response to the $\mathrm{O}_{2}$ metabolites. Ultrastructural examination of explants and cell cultures after exposure to stimulatory concentrations of purine $+\mathrm{XO}$ did not reveal morphological signs of toxicity, such as membrane blebbing, cell swelling, and/or vacuolization in the epithelial cells. In addition, release of $\mathrm{LDH}$, a marker of cytotoxicity, was not increased after incubation with $\mathrm{O}_{2}$ metabolites for $1 \mathrm{~h}$. Thus, $\mathrm{O}_{2}$ metabolite-mediated $\mathrm{HMG}$ release appeared to be an active phenomenon, and not merely a passive leakage of cellular contents due to nonspecific cellular lysis.

The cellular source(s) of the released HMG could not be determined from these experiments. It has been reported that macromolecular secretions in the airway lumen can originate from several cellular locations, such as the glycocalyx of surface-ciliated and secretory cells, and/or intracellular granules (20). Material from intracellular origins and cell surfaces both can be released upon appropriate stimulation, including exocytosis, cell surface shedding, and exposure to external stimuli, such as proteases (20). Accordingly, $\mathrm{O}_{2}$ metabolites could have stimulated release of both cell surface-associated and intracellular HMG.

Although the results clearly indicate that $\mathrm{O}_{2}$ metabolites stimulate HMG release, identification of the specific $\mathrm{O}_{2}$ metabolite(s) responsible for this effect is not simple since the various species are quite reactive, often reacting with each other. For example, $\mathrm{O}_{\overline{2}}$ formed by the action of $\mathrm{XO}$ upon purine is rapidly dismutated to $\mathrm{H}_{2} \mathrm{O}_{2}$, which in turn is converted, in the presence of $\mathrm{Fe}^{2+}$, to hydroxyl radical $(\cdot \mathrm{OH})(30)$. $\mathrm{O}_{\overline{2}}^{\overline{2}}$ also can contribute to formation of $\cdot \mathrm{OH}$ by converting $\mathrm{Fe}^{3+}$ to $\mathrm{Fe}^{2+}$. We found that addition of the $\mathrm{O}_{\overline{2}}^{\overline{2}}$ scavenger SOD inhibited partially the stimulatory response to purine $+\mathrm{XO}$, implicating $\mathrm{O}_{\overline{2}}^{-}$(at least in part) in stimulation of HMG release. Surprisingly, $\mathrm{H}_{2} \mathrm{O}_{2}$ per se did not appear to be involved in stimulated release. This was indicated by the results of several experiments. Addition of CAT, a scavenger of $\mathrm{H}_{2} \mathrm{O}_{2}$, did not alter purine $+\mathrm{XO}$-induced $\mathrm{HMG}$ release. Since neither enzymatically generated $\mathrm{H}_{2} \mathrm{O}_{2}$ (addition of glucose $+\mathrm{GO}$ ) nor $\mathrm{H}_{2} \mathrm{O}_{2}$ added directly to the cells enhanced $\mathrm{HMG}$ release, a direct role for extracellularly added $\mathrm{H}_{2} \mathrm{O}_{2}$ in the stimulatory response to purine $+\mathrm{XO}$ was not indicated. However, the stimulatory response to purine $+\mathrm{XO}$ was inhibited in both cell and organ cultures by addition of CAT coupled to PEG, a procedure which facilitates entry of CAT into cells (31). Since PEG-CAT has both $\mathrm{H}_{2} \mathrm{O}_{2}$ - and $\cdot \mathrm{OH}$-scavenging properties, one possible interpretation is that exposure of respiratory epithelial cells to extracellularly generated $\mathrm{O}_{2}$ metabolites may stimulate production of oxygen free radicals intracellularly, and it is these intracellularly generated active oxygen species which act to provoke HMG release. In support of this concept, HMG release also was inhibited after addition of the permeant $\mathrm{H}_{2} \mathrm{O}_{2}$ and $\cdot \mathrm{OH}$ scavenger, DMTU, but not by addition of the relatively weak and impermeable $\cdot \mathrm{OH}$ scavenger, mannitol (32). Thus, it would appear that intracellular production or 


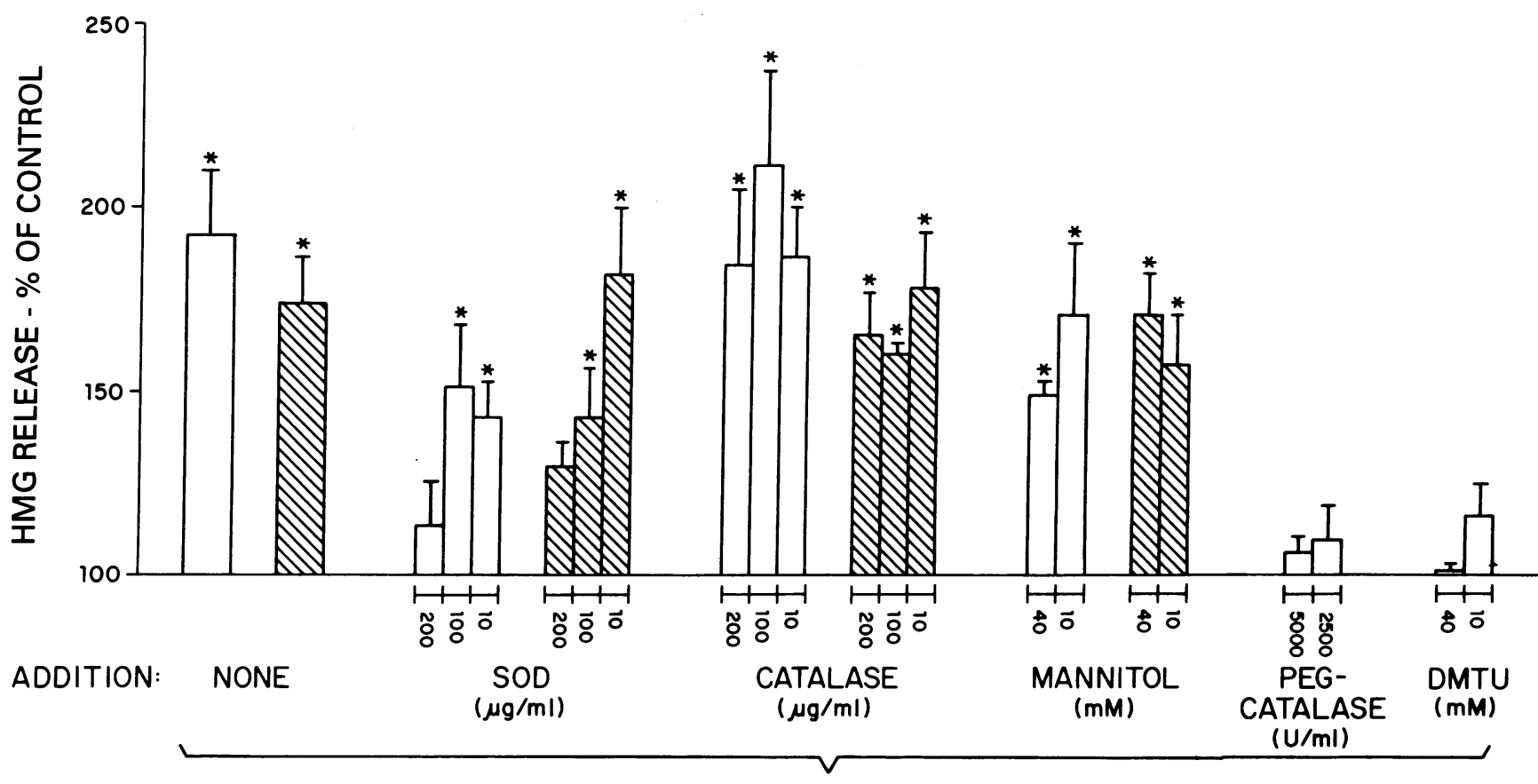

Purine $(0.2 \mathrm{mM})+$ Xanthine Oxidase $(0.02 \mathrm{U} / \mathrm{ml})$

Figure 5. Effect of addition of $\mathrm{O}_{2}$ metabolite scavengers on HMG release by explants of trachea from guinea pig (ם) or rabbit (घ) stimulated by purine $(0.2 \mathrm{mM})$ and XO $(0.02 \mathrm{U} / \mathrm{ml})$. SOD at $200 \mu \mathrm{g} / \mathrm{ml}$ inhibited, whereas CAT or mannitol did not affect, $\mathrm{O}_{2}$ metabolite-stimulated HMG release. PEG-CAT and DMTU inhibited enhanced HMG release. All values are means \pm 1 SEM for six or more determinations. Each asterisk indicates values that are significantly different $(P<0.05)$ from control values based on the Scheffe procedure for multiple analysis of variance $(28,29)$.

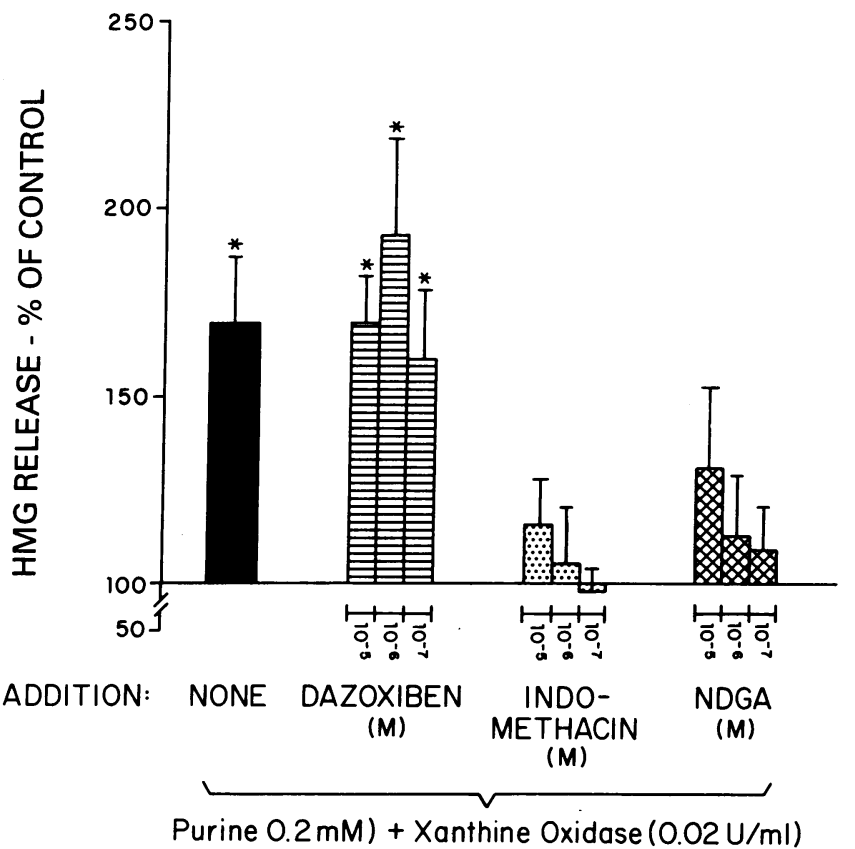

Figure 6. Effect of addition of inhibitors of arachidonic acid metabolism on release of HMG from guinea pig tracheal epithelial cell cultures stimulated by purine $+\mathrm{XO}$. Addition of either indomethacin or NDGA inhibited HMG release stimulated by purine + XO. By comparison, addition of the thromboxane synthetase inhibitor dazoxiben did not alter purine + XO-stimulated HMG release. All values are means \pm 1 SEM, expressed as percentage of control for eight determinations at each point. Each asterisk indicates values that are significantly different $(P<0.05)$ from control values as assessed by the Scheffe procedure for multiple analysis of variance $(28,29)$. intracellular activity of $\mathrm{O}_{2}$ metabolites is involved integrally in the stimulatory effect of purine $+\mathrm{XO}$ in tracheal epithelial cells.

The stimulatory effect of $\mathrm{O}_{2}$ metabolites on HMG release appeared to be mediated by $\mathrm{PGF}_{2 \mathrm{a}}$. First, inhibition of cyclooxygenase metabolism of arachidonic acid inhibited purine + XO-induced HMG release. Secondly, analysis by HPLC of culture media from cells exposed to purine $+\mathrm{XO}$ showed increased peak heights corresponding to $\mathrm{PGF}_{2 a}, 5-\mathrm{HETE}$, and 15-HETE. However, only addition of exogenous $\mathrm{PGF}_{2 \mathrm{a}}$ to cell cultures provoked HMG release, whereas addition of 15HETE (previously reported to be stimulatory to secretion of mucin in canine airways [33]) and 5-HETE did not affect HMG release (Fig. 8). Moreover, when separate HPLC fractions corresponding to $\mathrm{PGF}_{2 \mathrm{a}}$ (or other possibly stimulatory metabolites: PGD 2 , PGE, $\mathrm{LTC}_{4}, \mathrm{LTD}_{4}, \mathrm{LTE}_{4}$, and $\mathrm{LTB}_{4}$ ) were analyzed by RIA, the only significant change after exposure to purine $+\mathrm{XO}$ was in the amount of $\mathrm{PGF}_{2 \mathrm{a}}$. Thirdly, addition of $\mathrm{O}_{2}$ metabolite scavengers which inhibited purine + XO-stimulated HMG release (SOD, PEG-CAT, DMTU) also inhibited synthesis of $\mathrm{PGF}_{2 \mathrm{a}}$ by the epithelial cells, whereas addition of scavengers that did not inhibit HMG release (mannitol, free CAT) did not inhibit production of $\mathrm{PGF}_{2 \mathrm{a}}$. Fourthly, addition of indomethacin or NDGA decreased both $\mathrm{PGF}_{2 \mathrm{a}}$ production and mucin secretion, but indomethacin (and NDGA at concentrations above $10^{-5} \mathrm{M}$ ) did not scavenge $\mathrm{O}_{2}^{-}$or $\mathrm{H}_{2} \mathrm{O}_{2}$ in a cell-free system.

The effect of NDGA in inhibiting stimulated HMG release is somewhat puzzling, inasmuch as NDGA treatment mimicked the effects of indomethacin and inhibited increased HMG release after $\mathrm{O}_{2}$ metabolite exposure (Figs. 6 and 7). Moreover, unlike indomethacin, NDGA did not decrease 


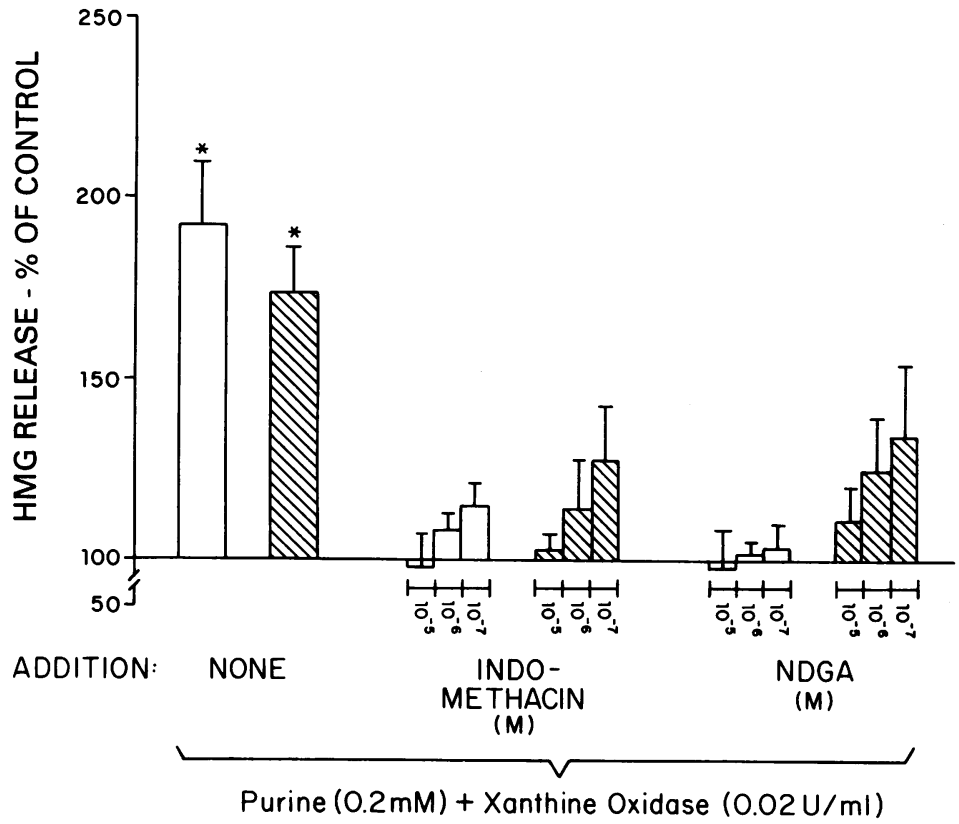

Figure 7. Effect of addition of inhibitors of arachidonic acid metabolism on release of HMG by rodent tracheal explants stimulated by purine $+\mathrm{XO}$. Addition of either indomethacin or NDGA to guinea pig ( $\square$ ) or rabbit ( $₫$ ) explants inhibited HMG release stimulated by purine $+\mathrm{XO}$. All values are means \pm 1 SEM, expressed as percentage of control for 12 determinations at each point. Each asterisk indicates values which are significantly different $(P<0.05)$ from control values as assessed by the Scheffe procedure for multiple analysis of variance $(28,29)$. constitutive production of $\mathrm{PGF}_{2 \mathrm{a}}$, but did inhibit $\mathrm{O}_{2}$ metabolite-stimulated $\mathrm{PGF}_{2 \mathrm{a}}$ production (Table II). Although NDGA can inhibit both cyclooxygenase and lipoxygenase, its effects on cyclooxygenase metabolism are usually manifest at a higher concentration than those used here. A possible explanation is that NDGA at $10^{-6} \mathrm{M}$ may have acted as a scavenger of $\mathrm{O}_{2}$ metabolites in these in vitro systems, although not appearing to do so in a cell-free system at concentrations lower than $10^{-5}$ M. Conversely, NDGA may have partially affected cyclooxygenase metabolism. While the exact mechanism of NDGA

Table I. Effects of Oxygen Metabolites on Production of Arachidonate Metabolites by Guinea Pig Respiratory Epithelial Cell Cultures

\begin{tabular}{|c|c|c|}
\hline $\begin{array}{c}\text { Arachidonate } \\
\text { metabolite }\end{array}$ & Untreated control cultures $*$ & Purine + XO-treated cultures $* \neq 0$ \\
\hline & pg/100 $\mathrm{\mu l}$ per $10^{5}$ cells & $\mathrm{pg} / 100 \mu \mathrm{l} \mathrm{per} 10^{5}$ cells \\
\hline $\mathrm{I}_{\mathrm{r}} \mathrm{PGF}_{2 \mathrm{a}}$ & $9.4 \pm 2.6$ & $38.0 \pm 1.9^{\prime \prime}$ \\
\hline I $_{\mathrm{r}}$ 15-HETE & $7.8 \pm 2.2$ & $21.2 \pm 5.6^{\prime \prime}$ \\
\hline Ir 5-HETE & $5.7 \pm 1.3$ & $9.9 \pm 1.0^{\prime \prime}$ \\
\hline $\mathrm{I}_{\mathrm{r}} \mathrm{PGE}_{2}$ & $1.3 \pm 1.1$ & $1.7 \pm 0.9^{1}$ \\
\hline $\mathrm{I}_{\mathrm{r}} \mathrm{PGD}_{2}$ & $9.8 \pm 1.8$ & $11.9 \pm 2.1^{\prime}$ \\
\hline $\mathrm{I}_{\mathrm{r}} \mathrm{LTB}_{4}$ & $2.0 \pm 0.4$ & $2.4 \pm 0.2^{1}$ \\
\hline $\mathrm{I}_{\mathrm{r}} \mathrm{LTC}_{4}$ & $16.9 \pm 1.7$ & $17.8 \pm 2.8^{\prime}$ \\
\hline $\mathrm{I}_{\mathbf{r}} \mathrm{LTD}_{4}$ & $11.9 \pm 0.8$ & $11.1 \pm 1.2^{\prime}$ \\
\hline $\mathrm{I}_{\mathrm{r}} \mathrm{LTE}_{4}$ & $10.7 \pm 1.4$ & $15.5 \pm 3.6^{\prime}$ \\
\hline
\end{tabular}

$\mathbf{I}_{\mathrm{r}}$, immunoreactive.

* Values are means \pm 1 SEM for four replicate experiments.

₹ Values are derived from radioimmunoassay of HPLC peaks corresponding to retention times for each metabolite. See Methods.

${ }^{8}$ Cultures exposed to purine $(0.2 \mathrm{mM})+\mathrm{XO}(0.02 \mathrm{U} / \mathrm{ml})$ for $1 \mathrm{~h}$.

" Value significantly different $(P<0.05)$ from untreated control

values as assessed by Student's $t$ test (28).

' Value not significantly different $(P>0.05)$ from untreated control values as assessed by Student's $t$ test (28). inhibition of $\mathrm{O}_{2}$ metabolite-stimulated HMG release and $\mathrm{PGF}_{2 \mathrm{a}}$ production remains to be resolved, thromboxane does not appear to be involved in this response since the thromboxane synthetase inhibitor, dazoxiben, did not decrease oxidantstimulated HMG release. The latter finding indicates that the arachidonic acid response to purine $+\mathrm{XO}$ of respiratory epithelium is different from that of isolated perfused lung (7).

Exposure of rodent airway epithelium to $\mathrm{O}_{2}$ metabolites appeared to provoke $\mathrm{HMG}$ release via a $\mathrm{PGF}_{2 \mathrm{a}}$-dependent mechanism, possibly involving an autocrine or paracrine type of stimulation. Obviously, other eicosanoids or their numerous metabolites which were not assayed nor tested for their effects on HMG release also could be involved in mediating $\mathrm{O}_{2}$ metabolite-induced HMG release. Many of these compounds can be quite potent, even at very low concentrations. In addition, many of these lipid mediators, including HETES and LTs, can act synergistically in modulating various cell functions. A further complicating factor is the ability of arachidonic acid itself to stimulate $\mathrm{HMG}$ release at $10^{-5}$ to $10^{-8} \mathrm{M}$ (data not shown). Complex bidirectional interactions between intracellular free radicals and arachidonic acid metabolism have been reported: oxygen free radicals are generated during the course of arachidonic acid metabolism (14), and, conversely, intracellular $\mathrm{O}_{2}$ metabolites stimulate arachidonic acid release and metabolism (34). However, these theoretical considerations do not alter the findings reported here that indicate epithelial-derived $\mathrm{PGF}_{2 \mathrm{a}}$ is a major contributor to respiratory HMG release after exposure to $\mathrm{O}_{2}$ metabolites. $\mathrm{PGF}_{2 \mathrm{a}}$ is a major cyclooxygenase product of respiratory epithelium in several species (27) and, accordingly, may play an important role in modulating airway secretion under normal (constitutive) conditions and in response to a number of exogenous and endogenous stimuli.

In concordance with our findings, $\mathrm{O}_{2}$ metabolites have been linked to stimulation of arachidonic acid metabolism in a variety of cell types. Oxygen radicals (34), ozone (35), hyperoxia (36), and lipid oxidants (37) enhance both cyclo- and lipoxygenase metabolism of arachidonic acid, probably 

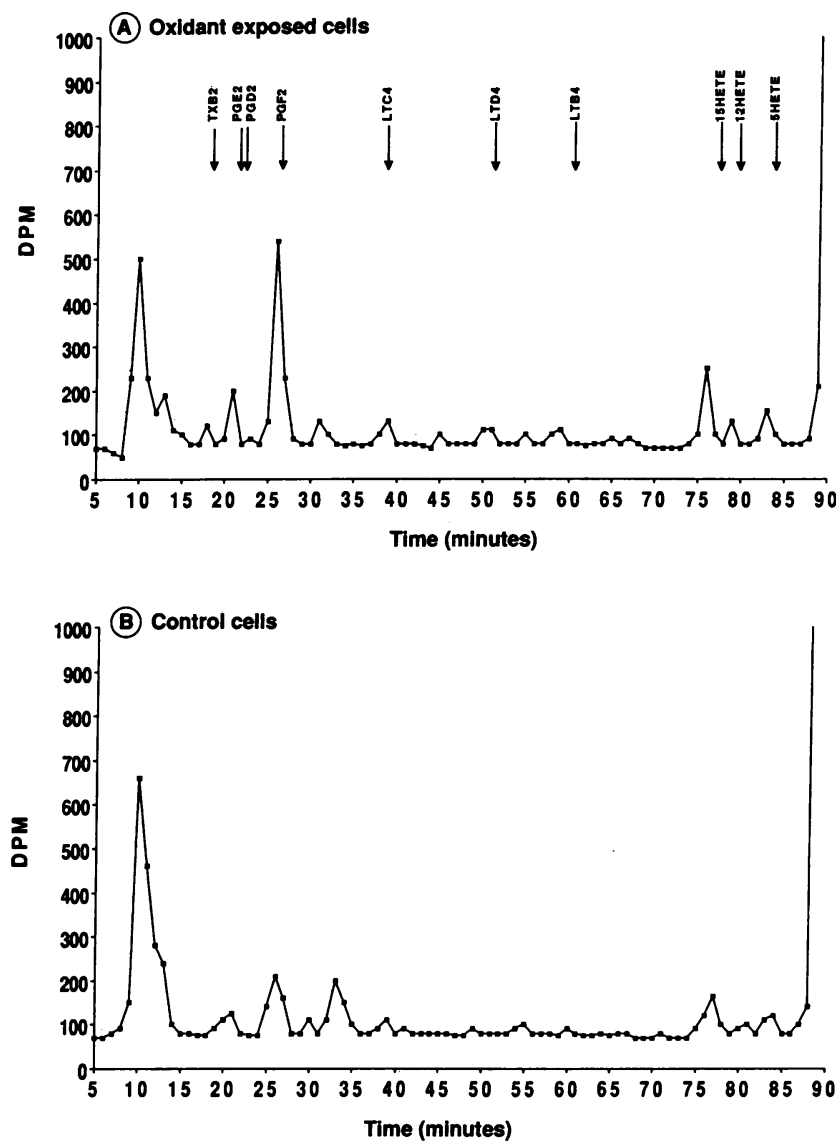

Figure 8. Profile of $\left[{ }^{3} \mathrm{H}\right]$ eicosanoid production by radiolabeled guinea pig epithelial cells in culture, as determined by reverse-phase HPLC separation of the culture medium. $(A)$ Radiolabeled metabolites produced by cultures exposed to purine $(0.2 \mathrm{mM})$ and XO 0.02 $\mathrm{U} / \mathrm{ml}$ ) for $1 \mathrm{~h}$. Elution times of cyclooxygenase and lipoxygenase standards, as measured by ultraviolet absorbance, are indicated above this profile. $(B)$ Radiolabeled metabolites produced by control cultures exposed only to medium with no additions for $1 \mathrm{~h}$. Exposure to purine + XO appeared to stimulate production of arachidonate metabolites at approximate retention times of 26,77 , and 84 min, corresponding to standards of PGF $_{2 a}, 15-\mathrm{HETE}$, and 5-HETE, respectively. Each point is the mean for assays done on four separate samples.

through activation of cellular phospholipase $A_{2}$, an enzyme that catalyzes release of arachidonic acid from membrane lipids (38). In particular, explants of guinea pig gallbladder exposed to exogenously generated $\mathrm{O}_{2}$ metabolites showed enhanced mucin secretion which was inhibitable by addition of indomethacin or scavengers of $\mathrm{H}_{2} \mathrm{O}_{2}$ and $\cdot \mathrm{OH}$ (39). Relatedly, bovine bronchial epithelial cells produce (and release) $\mathrm{H}_{2} \mathrm{O}_{2}$ in response to a variety of inflammatory stimuli, including platelet-activating factor, phorbol myristate acetate (PMA), $\mathbf{L T B}_{\mathbf{4}}$, ionomycin, and neutrophil-derived elastase (40). It is of interest that many of these same inflammatory mediators: plateletactivating factor (11), PMA (41), and elastase $(20,21)$ also stimulate secretion/release of mucinlike glycoproteins by airway epithelium.

Generation of active $\mathrm{O}_{2}$ metabolites, metabolism of arachidonic acid, and secretion/release of various macromolecules may be interdependent processes in many epithelial tis-

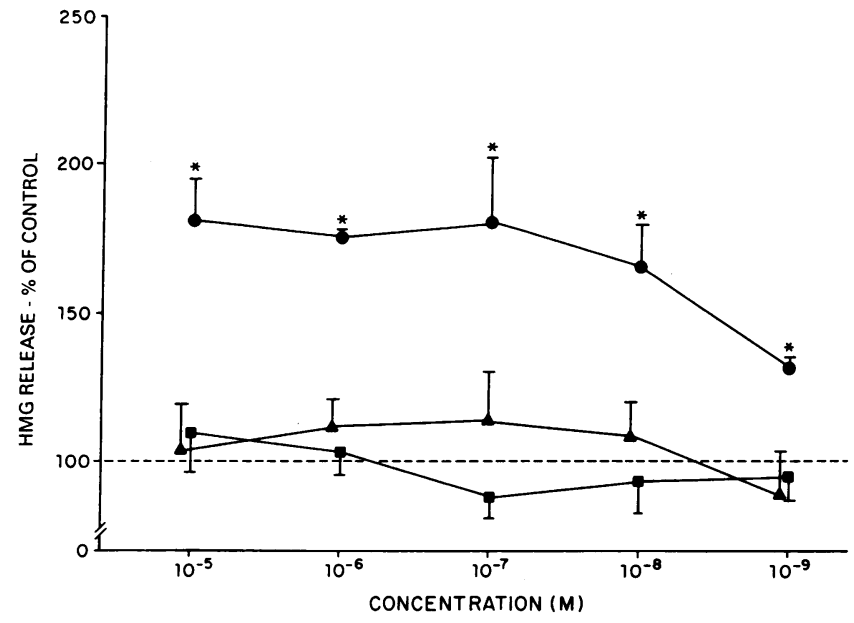

Figure 9. Effect of addition of arachidonate metabolites on HMG release by guinea pig epithelial cell cultures. Addition of $\mathrm{PGF}_{2 \mathrm{a}}(\bullet)$ over a range of concentrations stimulated HMG release, whereas 15and 5-HETE ( $\triangle$ and $n$, respectively) did not alter HMG release. All values are means \pm 1 SEM, expressed as percentage of control for eight determinations at each point. Each asterisk indicates values which are significantly different $(P<0.05)$ from control values as assessed by Student's $t$ test analysis (28).

sues. In the respiratory airways, these interconnected mechanisms could be central to pathological secretion of respiratory mucus and resultant airway obstruction after inhalation of a variety of xenobiotic compounds, as well as following exposure to increased local levels of endogenously generated inflammatory and immune mediators which can recruit $\mathrm{O}_{2}$ metabolite-releasing neutrophils and mononuclear cells to the im-

Table II. Effects of Oxygen Metabolites on Production of PGF $2 a$ by Guinea Pig Respiratory Epithelial Cell Cultures

\begin{tabular}{lc}
\hline \multicolumn{1}{c}{ Addition } & $\begin{array}{c}\mathrm{I}_{\mathrm{f}} \mathrm{PGF}_{2 \mathrm{a}} \\
\text { accumulation in } \\
\text { medium }\end{array}$ \\
\hline & $p g / 100 \mu l$ per $10^{5}$ cells \\
None & $12.3 \pm 2.6(8)$ \\
Purine $(0.2 \mathrm{mM})+\mathrm{XO}(0.02 \mathrm{U} / \mathrm{ml})$ & $51.9 \pm 6.7^{\S}(8)$ \\
Purine $(0.02 \mathrm{mM})+\mathrm{XO}(0.02 \mathrm{U} / \mathrm{ml})$ & \\
$\quad+$ "Unbound" Catalase $(200 \mu \mathrm{g} / \mathrm{ml})$ & $39.9 \pm 5.1^{8}(3)$ \\
Mannitol $(40 \mathrm{mM})$ & $43.7 \pm 2.1^{8}(3)$ \\
SOD $(200 \mu \mathrm{g} / \mathrm{ml})$ & $21.1 \pm 6.9^{\prime \prime}(3)$ \\
PEG-CAT $(2,500 \mathrm{U} / \mathrm{ml})$ & $15.8 \pm 3.3^{\prime \prime}(3)$ \\
DMTU $(40 \mathrm{mM})$ & $18.7 \pm 4.1^{\prime \prime}(3)$ \\
Indomethacin $\left(10^{-5} \mathrm{M}\right)$ & $1.1 \pm 1.0^{\S}(3)$ \\
NDGA $\left(10^{-6}\right)$ & $11.4 \pm 3.7^{\prime \prime}(3)$
\end{tabular}

* All values are means \pm 1 SEM. Values in parentheses are numbers of replicate experiments.

¥ Values are derived from radioimmunoassay of HPLC peaks corresponding to retention time for $\mathrm{PGF}_{2 \mathrm{a}}$. See Methods.

8 Value significantly different $(P<0.05)$ from untreated control values as assessed by $S$ cheffe procedure $(28,29)$.

"Value not significantly different $(P>0.05)$ from untreated control values as assessed by Scheffe procedure $(28,29)$. 
mediate vicinity of airway epithelium. Indeed, over $60 \%$ of the cells at the air-surface interface of human upper airways consist of neutrophils and macrophages (42). Regardless of their origin, toxic $\mathrm{O}_{2}$ metabolites can have a variety of deleterious effects within the lung and airways, and may mediate several pathological processes. Our studies extend these findings by demonstrating that an additional effect of $\mathrm{O}_{2}$ metabolites may include $\mathrm{PGF}_{2 \mathrm{a}}$-dependent stimulation of $\mathrm{HMG}$ release by tracheobronchial epithelium. This pathogenetic mechanism could relate oxidant injury to hypersecretion of mucus and/or other macromolecules, and the resultant compromised pulmonary defense mechanisms may thereby increase susceptibility to acute and chronic obstructive disease (43).

\section{Acknowledgments}

The authors thank Janet E. Schwarz, Nancey J. Akley, Paul Joyce, and Elaine M. Berger for their excellent technical assistance. Dr. Joe M. McCord of the University of South Alabama, Mobile, AL, kindly provided xanthine oxidase isolated without proteases for certain experiments.

This work was supported by grants HL-36982 and HL-37636 from the National Institutes of Health, a grant from Hoffmann La Roche, Inc., Nutley, NJ, and a grant from the State of North Carolina. This work was completed during the tenure of an Established Investigator Award from the American Heart Association to Dr. Adler.

\section{References}

1. Jackson, J. H., I. U. Schraufstatter, K. Vosbeck, R. Sauerhaber, S. A. Weitzman, and C. G. Cochrane. 1987. Role of oxidants in DNA damage: hydroxyl radical mediates the synergistic DNA damaging effects of asbestos and cigarette smoke. J. Clin. Invest. 80:1090-1095.

2. Gormley, I. P., M. J. Kowolik, and R. T. Cullen. 1985. The chemiluminescent response of human phagocytic cells to mineral dusts. Br. J. Exp. Pathol. 66:409-416.

3. Menzel, D. B. 1976. The role of free radicals in the toxicity of air pollutants, nitrogen oxides, and ozone. In Free Radicals in Biology, Volume II. W. A. Pryor, editor. Academic Press, Inc., New York. 181-202.

4. White, C. W., and J. E. Repine. 1985. Pulmonary antioxidant defense mechanisms. Exp. Lung Res. 8:81-96.

5. Smith, R. J., B. J. Bowman, and S. S. Iden. 1984. Stimulation of the human neutrophil superoxide anion-generating system with 1-0hexadecyl/octadecyl-2-acetyl-sn-glyceryl-3-phosphorycholine. Biochem. Pharmacol. 33:973-978.

6. Johnson, K. J., J. C. Fantone, J. Kaplan, and P. A. Ward. 1981. In vivo damage of rat lungs by oxygen metabolites. J. Clin. Invest. 67:983-993.

7. Tate, R. M., K. M. Van Bethuysen, D. M. Shasby, I. F. McMurtry, and J. E. Repine. 1982. Oxygen radical mediated permeability edema and vasoconstriction in isolated perfused rabbit lungs. Am. Rev. Respir. Dis. 126:802-806.

8. Tate, R. M., H. G. Morris, W. R. Schroeder, and J. E. Repine. 1984. Oxygen metabolites stimulate thromboxane production and vasoconstriction in isolated saline-perfused rabbit lungs. J. Clin. Invest. 74:608-613.

9. Phipps, R. J., S. M. Denas, M. W. Sielczak, and A. Wanner. 1986. Effects of $0.5 \mathrm{ppm}$ ozone on glycoprotein secretion, ion, and water fluxes in sheep trachea. J. Appl. Physiol. 60:918-927.

10. Mossman, B. T., K. B. Adler, L. M. Jean, and J. E. Craighead. 1982. Mechanisms of hypersecretion in rodent tracheal explants after exposure to chrysotile asbestos: studies using lectins. Chest. 81:23S$25 \mathrm{~S}$.

11. Adler, K. B., J. E. Schwarz, W. H. Anderson, and A. F. Welton.
1987. Platelet activating factor stimulates secretion of mucin by explants of rodent airways in organ culture. Exp. Lung Res. 13:25-47.

12. Hemler, M. E., H. W. Cook, and W. E. M. Lands. 1979. Prostaglandin synthesis can be triggered by lipid peroxides. Arch. Biochem. Biophys. 193:340-345.

13. Marom, Z., J. H. Shelhamer, M. K. Bach, D. R. Morton and M. Kaliner. 1982. Slow reacting substances, leukotrienes $C_{4}$ and $D_{4}$, increase the release of mucus from human airways in vitro. Am. Rev. Resp. Dis. 126:449-451.

14. Kontos, H. A., E. P. Wei, J. T. Povlishock, W. D. Dietrich, C. J. Magiera, and E. F. Ellis. 1980. Cerebral arteriolar damage by arachidonic acid and prostaglandin $\mathrm{G}_{2}$. Science (Wash. DC). 209:12421245.

15. Adler, K. B., J. E. Schwarz, M. J. Whitcutt, and R. Wu. 1987. A new chamber system for maintaining differentiated guinea pig respiratory epithelial cells between air and liquid phases. Biotechniques. 5:462-465.

16. Whitcutt, M. J., K. B. Adler, and R. Wu. 1988. A biphasic chamber system for maintaining polarity of differentiation of cultured respiratory tract epithelial cells. In Vitro Cell Dev. Biol. 24:420-428.

17. Waud, W. R., F. O. Brady, R. D. Wiley, and K. V. Rajagopalan. 1975. A new purification procedure for bovine milk xanthine oxidase: effect of proteolysis on the subunit structure. Arch. Biochem. Biophys. 169:695-701.

18. Adler, K. B., J. Khosla, and K. C. Kim. 1988. Morphometric and biochemical characterization of a chamber system for maintaining differentiated guinea pig respiratory mucosal cells between air and liquid phases. Am. Rev. Respir. Dis. 137:14. (Abstr.)

19. Kim, K. C., J. I. Rearick, P. Nettesheim, and A. M. Jetten. 1985. Biochemical characterization of mucin secreted by hamster tracheal epithelial cells in primary culture. J. Biol. Chem. 260:40214027.

20. Kim, K. C., K. Wasano, R. M. Niles, J. E. Schuster, P. J. Stone, and J. S. Brody. 1987. Human neutrophil elastase releases cell surface mucins from primary cultures of hamster tracheal epithelial cells. Proc. Natl. Acad. Sci. USA. 84:9304-9308.

21. Adler, K. B., D. D. Hendley, and G. S. Davis. 1986. Bacteria associated with chronic obstructive pulmonary disease elaborate extracellular products that stimulate secretion of mucin by explants of guinea pig airways. Am. J. Pathol. 125:501-514.

22. Adler, K. B., P.-W. Cheng, and K. C. Kim. 1989. Characterization of guinea pig tracheal epithelial cells maintained in biphasic organotypic culture: cellular composition and biochemical analysis of secretions. Am. J. Respir. Cell. Mol. Biol. In press.

23. Cheng, P.-W., T. F. Boat, K. Cranfill, J. R. Yankaskas, and R. C. Boucher. 1989. Increased sulfation of glycoconjugates by cultured nasal epithelial cells from patients with cystic fibrosis. J. Clin. Invest. In press.

24. Buckley, B. J., A. K. Tanswell, and B. A. Freeman. 1987. Liposome-mediated augmentation of catalase in alveolar Type II cells protects against $\mathrm{H}_{2} \mathrm{O}_{2}$ injury. J. Appl. Physiol. 63:360-367.

25. McCord, J. M., and I. Fridovich. 1969. Superoxide dismutase: an enzymic function for erythrocuprein. J. Biol. Chem. 244:60496055 .

26. Thurman, R. G., H. G. Ley, and R. Scholz. 1972. Hepatic microsomal ethanol oxidation: hydrogen peroxide formation and the role of catalase. Eur. J. Biochem. 25:420-430.

27. Eling, T. E., R. M. Danilowicz, D. C. Henke, K. Sivarajah, J. R. Yankaskas, and R. V. Boucher. 1986. Arachidonic acid metabolism by canine tracheal epithelial cells. J. Biol. Chem. 261:12841-12849.

28. Woolson, R. F. 1987. Statistical Methods for the analysis of biomedical data. John Wiley \& Sons, New York. 513 pp.

29. Scheffe, H. 1953. A method for judging all contrasts in the analysis of variance. Biometrika. 40:87-104.

30. Freeman, B. A., and J. D. Crapo. 1982. Biology of disease: free radicals and tissue injury. Lab. Invest. 67:412-426.

31. McDonald, R. J., E. M. Berger, C. W. White, J. G. White, B. A. Freeman, and J. E. Repine. 1985. Effect of superoxide dismutase en- 
capsulated in liposomes or conjugated with polyethylene glycol on neutrophil bactericidal activity in vitro and bacterial clearance in vivo. Am. Rev. Respir. Dis. 131:633-637.

32. Fox, R. B. 1984. Prevention of granulocyte-mediated oxidant lung injury in rats by a hydroxyl radical scavenger, dimethylurea. $J$. Clin. Invest. 74:1456-1464.

33. Johnson, H. G., M. L. McNee, and J. M. Braughlen. 1987. Inhibitors of metal-catalyzed lipid peroxidation reactions inhibit mucus secretion and 15-HETE levels in canine trachea. Prostaglandins Leukotrienes Med. 30:123-132.

34. Taylor, L., M. J. Menconi, and P. Polgar. 1983. The participation of hydroperoxides and oxygen radicals in the control of prostaglandin synthesis. J. Biol. Chem. 258:6855-6857.

35. Leikauf, G. D., K. E. Driscoll, and H. E. Wey. 1988. Ozone-induced augmentation of eicosanoid metabolism in epithelial cells from bovine trachea. Am. Rev. Respir. Dis. 137:435-442.

36. Freeman, B. A., M. K. Topolosky, and J. D. Crapo. 1982. Hyperoxia increases oxygen radical production in rat lung homogenates. Arch. Biochem. Biophys. 216:477-484.

37. Gurtner, G. H., A. Knoblauch, P. L. Smith, H. Sies, and N. F. Adkinson. 1983. Oxidant- and lipid-induced pulmonary vasoconstriction mediated by arachidonic acid metabolites. J. Appl. Physiol. 55:949-954
38. Au, A., M. P. H. Chan, and R. A. Fishman. 1985. Stimulation of phospholipase $A_{2}$ activity by oxygen-derived free radicals in isolated brain capillaries. J. Cell. Biochem. 27:449-453.

39. Hale, W. B., B. Turner, and J. T. Lamont. 1987. Oxygen radicals stimulate guinea pig gallbladder glycoprotein secretion in vitro. Am. J. Physiol. 253:G627-G630.

40. Lopez, A., S. Shoji, J. Fujita, R. Robbins, and S. Rennard. 1988. Bronchoepithelial cells can release hydrogen peroxide in response to inflammatory stimuli. Am. Rev. Respir. Dis. 137:81. (Abstr.)

41. Rieves, R. D., J. D. Lundgren, C. Logun, J. E. Parrillo, and J. H. Shelhamer. 1988. The effects of protein kinase $C$ activating agents on glycoconjugate secretion from feline tracheal explants. Am. Rev. Respir. Dis. 137:10. (Abstr.)

42. Rankin, J. A., T. Marcy, S. Smith, J. Olchowski, J. Sussman, and W. W. Merrill. 1988. Human airway lining fluid (ALF): cellular and protein constituents. Am. Rev. Respir. Dis. 137:5. (Abstr.)

43. Euler, G. L., D. E. Abbey, J. E. Hodgkin, and A. R. Magie. 1988. Chronic obstructive pulmonary disease symptom effects of long-term cumulative exposure to ambient levels of total oxidants and nitrogen dioxide in California Seventh-day Adventist residents. Arch. Environ. Health. 43:279-285. 